76

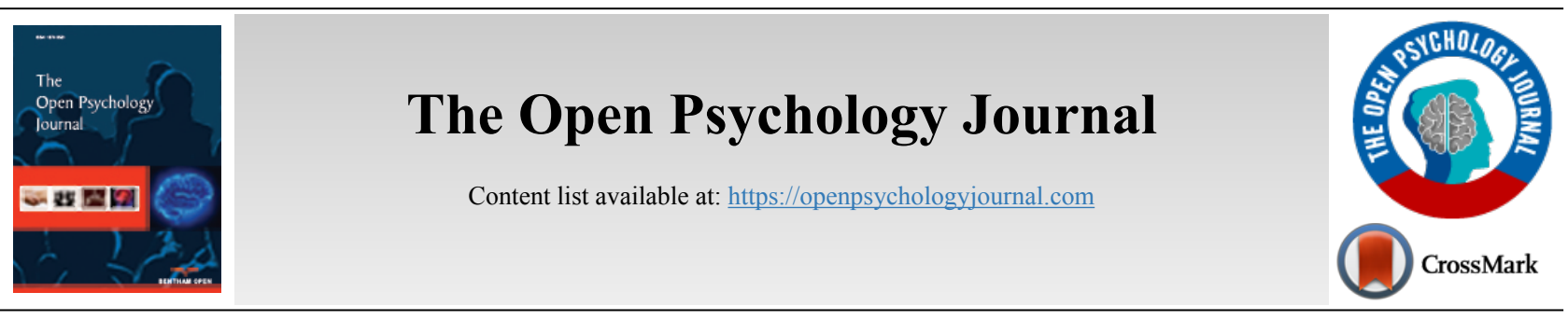

RESEARCH ARTICLE

\title{
Influence of Working Memory on Academic Achievement and Quality of Life in Children with Beta-Thalassemia Major
}

\author{
Uni Gamayani ${ }^{1, *}$, Ni Luh Meidha Dini Lestari ${ }^{1}$, Ahmad Rizal Ganiem ${ }^{1}$ and Ramdan Panigoro ${ }^{2}$ \\ ${ }^{I}$ Department of Neurology, Faculty of Medicine, Universitas Padjadjaran/ Hasan Sadikin General Hospital, Jalan Pasteur no 38, Indonesia \\ ${ }^{2}$ Department of Biomedical Science, Faculty of Medicine, Universitas Padjadjaran/ Hasan Sadikin General Hospital, RSP Unpad, Jalan Eijkman No \\ 38, Indonesia
}

\begin{abstract}
:
Background:

Children with beta-thalassemia major may suffer from working memory impairment. For a more refined understanding of this issue, we assessed working memory function in beta-thalassemia children and evaluated its influence on academic achievement and quality of life.

Methods:

This was a cross-sectional study involving 60 beta-thalassemia children aged 8-12 years. All participants underwent a working memory assessment using the digit span and were interviewed using academic achievement and Indonesian version of PedsQL 4.0 questionnaires. Working memory in beta-thalassemia children significantly influences their quality of life, both directly $(\beta=0.32)$ and indirectly, through their academic achievement $(\beta=0.639)$. Longer duration of transfusion $(p=0.01)$ is significantly related to poorer working memory, while lower hemoglobin level ( $p=0.81)$ and higher ferritin level $(\mathrm{p}=0.24)$ are not significantly associated with working memory.

\section{Conclusion:}

We concluded that working memory influences the quality of life in beta-thalassemia children, both directly and indirectly, through their academic achievement.
\end{abstract}

Keywords: Academic achievement, Digit span, PedsQL, Quality of life, Thalassemia, Working memory.

\begin{tabular}{l|l|l|l} 
Article History & Received: October 29, 2018 & Revised: January 03, 2019 & Accepted: March 10, 2019
\end{tabular}

\section{INTRODUCTION}

Thalassemia is a group of inherited blood disorders caused by defects in the synthesis of globin chains of hemoglobins [1]. It is considered as one of the most common genetic diseases worldwide [2]. Indonesia is among the group of countries with a high prevalence of thalassemia [3] with an estimated carrier rate of $8 \%[4]$. The burden of this disorder in many regions is of such a magnitude that it represents a major public health concern [5]. Although the life expectancy of thalassemia patients has markedly improved over the last few decades, patients still suffer from many complications including neurological complications such as cognitive deficits [6].

Working memory has been a major topic of cognitive research for the past years [7]. It is defined as a dynamic

* Address correspondence to this author at the Department of Neurology, Faculty of Medicine, Universitas Padjadjaran/ Hasan Sadikin General Hospital, Jalan Pasteur no 38, Indonesia; Tel: +62222036984; E-mail: gamayani@yahoo.com processing system which includes temporary storage and manipulation of information [8]. In everyday life, working memory is essential for many cognitive processes such as language comprehension, planning or problem solving, and fluid intelligence [9]. Hence, working memory is thought to be more highly related to learning process than any other cognitive factors, and low working memory capacity seems to be a high-risk factor for underachievement in early school years $[10,11]$. Without early intervention, working memory difficulties are not spontaneously corrected as a child develops and impedes individual academic success [11].

Working memory involves many parts of the brain regions including prefrontal, frontal, lateral temporal, and parietal areas [12 - 14]. Some of these areas are known to be affected in thalassemic patients. Ischemic brain lesions as detected by MR imaging study are found mostly in basal ganglia, frontal, and parietal area [15]. Reduced or absent beta globin chain synthesis in thalassemia results in chronic hypoxic state as a 
result of chronic anemia $[16,17]$ and hemostatic changes leading to hypercoagulability that is involved in susceptibility to vaso-occlusion and, eventually, ischemic lesions in thalassemic patients [18 - 20]. While iron deposits are also commonly found, as thalassemic patients need regular blood transfusions [21 - 23], they are mostly detected in basal ganglia and temporal cortex [24].

The assessment of health-related quality of life is an important marker of health outcome for children, especially those with chronic conditions [25]. Children with beta thalassemia usually have a lower quality of life score compared to their healthy peers [26], with school functioning subscale being the most affected [27]. A previous study stated that low school functioning score in beta thalassemia children was influenced by low school attendance due to the great need of transfusion and hospitalization [28]. The influence of working memory on academic achievement and quality of life in children with beta thalassemia has never been studied.

\section{METHODS}

\subsection{Participants and Recruitment}

This was a cross-sectional study conducted in the outpatient clinic of Pediatric Thalassemia Unit of Dr. Hasan Sadikin General Hospital, Bandung, Indonesia during August to December 2016. The protocol of the study was approved by the Institutional Ethics Committee.

Inclusion criteria of this study were children age 8-12 years old who have already been diagnosed with beta thalassemia, undergone regular transfusion in the outpatient clinic of Pediatric Thalassemia Unit of Dr. Hasan Sadikin General Hospital, Bandung, Indonesia, and registered as an active student in formal school. Laboratory examinations showed a serum ferritin level of more than $1,000 \mu \mathrm{g} / \mathrm{L}$ and a pretransfusion serum hemoglobin level of less than $7 \mathrm{~g} / \mathrm{dL}$ for the last 3 months. Patients who had hearing disturbances, history of infectious diseases, chronic health conditions, central nervous system infections, head injuries, intracranial tumors, epilepsy, and other intracranial lesions based on information collected from medical report, parental report, and routine neurological examination were excluded from this study.

All eligible patients and their parents were consecutively approached as they came in for their regular transfusion schedule at the outpatient clinic of the Pediatric Thalassemia Unit during data collection period. Written parental informed consent and the child's assent were obtained prior to participation in the study. At the beginning of the examination and interview, all respondents were informed of the objectives of the study and were assured that all responses would be kept confidential.

\subsection{Instrument}

We assessed working memory of all eligible patients using the digit span examination. Digit span is a subtest of Wechsler Intelligence Scale for Children-Processing Instrument which has been validated and widely used as a single test. Methodologically, span tasks have been proven to be both reliable and valid measures of working memory capacity [29]. Digit span is frequently used in working memory assessment and is designed to be applicable in different countries, cultures, and languages [30]. The reliability scores of digit span forward test and digit span backward test are 0.891 and 0.598 , respectively [31].

In this study, digit span was measured for forward and backward (reverse-order) recalls of digit sequences. Forward digit span was used as a measure of the phonological loop of Baddeley's working memory model, whereas backward digit span involved its central executive part. Digit sequences were presented beginning with a length of two digits and two trials were presented at each increasing list length. Each digit was delivered verbally with a clear voice in 1 second interval. Testing ceased when the patient failed to accurately report either trial at one sequence length or when the maximum list length was reached ( 9 digits forward, 8 backward). The total number of lists reported correctly in forward span and backward span was combined to produce the total correct score.

Academic achievement was assesed using adapted version of the Department of Health and Human Service United Stated Instrument (cronbach alpha, 0.821). This instrument consists of 20 questions for subjective academic behaviours. Answers to the questions were obtained from patients interview and parental or teacher report for information about school marks in five core subjects. Each mark was then converted into a score to obtain academic performance objective data. We also asked parents about school attendance of their children for the last 3 months.

Quality of life assessment was performed using the Indonesian version of Pediatric Quality of Life Inventory ${ }^{\mathrm{TM}}$ (PedsQL ${ }^{\mathrm{TM}}$ ) 4.0 Generic Core Scale, which is a child selfreport questionnaire for $8-12$ years old age range. The questionnaire consists of 23 items: 8 items on physical functioning, 5 items on emotional functioning, 5 items on social functioning, and 5 items on school functioning. PedsQL items ask about how much of a problem a particular thing has been for patients during this past month. Item responses are measured on a five-point rating scale. Each scale has a score ranging from 0-100, in which a higher score indicates a higher QOL. PedsQL has demonstrated good internal consistency and validity in large samples of children with acute and chronic health conditions.

\subsection{Statistical Analysis}

Data analysis was performed using $\operatorname{IBM}{ }^{\circledR} \quad$ SPSS ${ }^{\circledR}$ Statistics version 17.0 program. Results were expressed in mean \pm standard deviation for quantitative variables and in number and percentage for qualitative ones. The association between working memory score and severity of thalassemia was generated using multiple linear regression analysis.

The interaction between working memory, academic achievement and quality of life variable was identified using path analysis. Path analysis is a variation of multiple-regression analysis and is useful for analyzing a number of issues involved in causal analysis. It holds strength because it allows researchers to study direct and indirect effects simultaneously with multiple independent and dependent variables. Path 


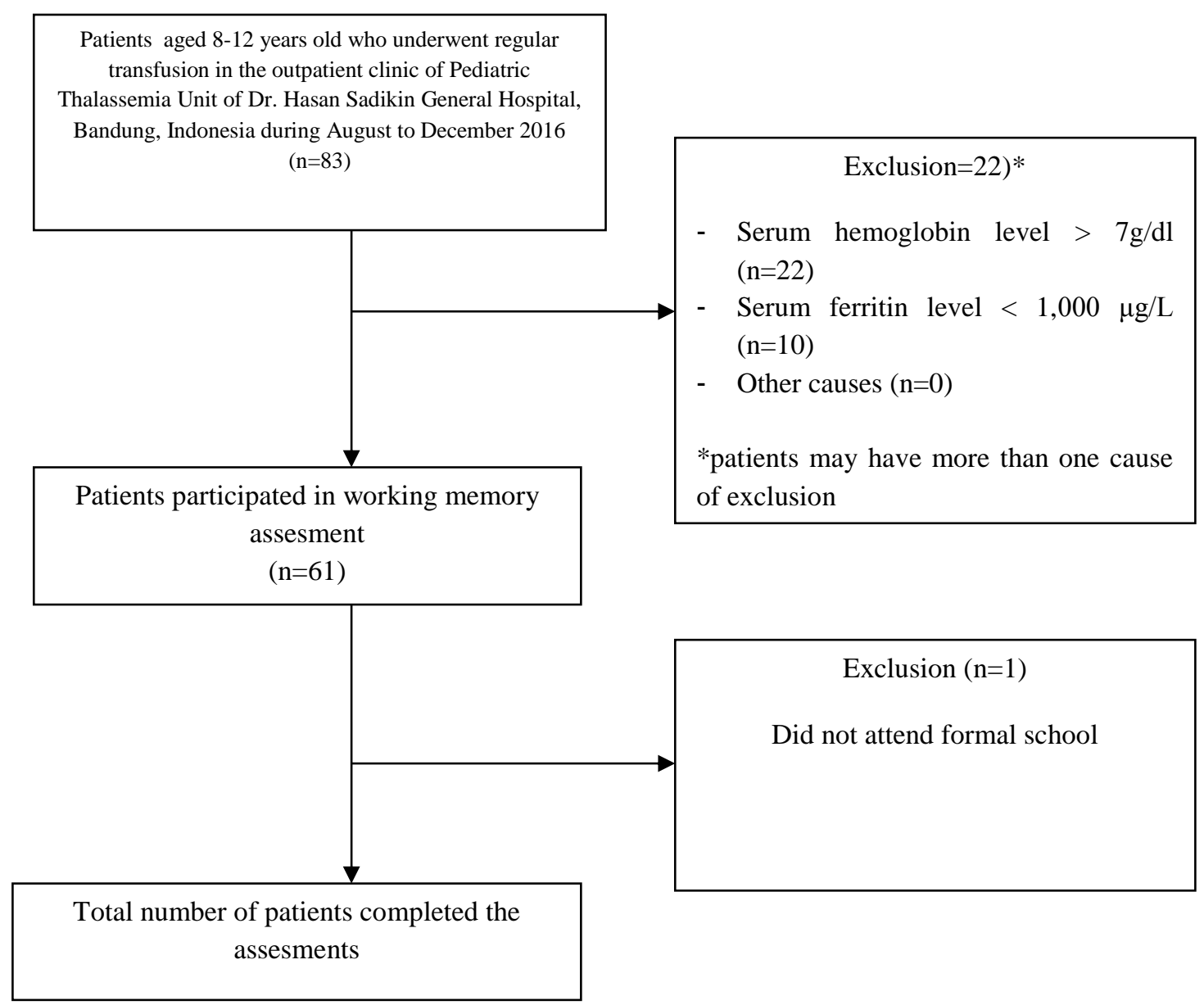

Fig. (1). Flow diagram of patient inclusion/exclusion.

analysis is the most useful when the researcher has a clear hypothesis to test, or a small number of hypotheses, all of which can be represented within a single path diagram [32].

The first step in our analysis was the initial path model (the hypothesized model), followed by the second step, the final model, which was devised by deleting the insignificant paths from the initial model. The goodness of fit between the data and the models was estimated by P-values for the Chi-squared test, Root Mean Square Error of Approximation (RMSEA), Goodness-of-Fit Index (GFI), Adjusted Goodness-of-Fit Index (AGFI), Normed Fit Index (NFI), and Comparative Fit Index (CFI). The criteria for a good fit were $\mathrm{P}>0.05$, RMSEA $<.05$, GFI $>0.9$, AGFI $>0.9$, NFI $>0.9$ and $\mathrm{CFI}>0.9 .33$.

\section{RESULTS}

From 83 beta thalassemia patients underwent transfusion during August to December 2016, 60 completed all assessments and were analysed. Details regarding selection of patients are presented in Fig. (1).

The mean (SD) age of patients was 10.23 (1.15) years old with no significant difference beetwen genders ( 31 females and 29 males). The mean (SD) pretransfusion hemoglobin level was $6.04(0.65) \mathrm{g} / \mathrm{dL}$ whereas the serum ferritin level and duration of illness were 4,297.90 $(2,116.42)$ and $9.2(1.46)$ years, respectively. Almost three-quarter (71.67\%) of the patients have a total digit span score below global average score with the mean (SD) score of 7.47 (1.7). The mean (SD) total score of academic achievement was 61.87 (14.97) while the mean (SD) total score of quality of life was 70.05 (14.42). School functioning subscale was the most impaired aspect in the quality of life in this study. Details regarding characteristics of the patients are presented in Table $\mathbf{1}$.

The state of thalassemia and its association with working memory were assessed by obtaining the regression weights and the p-values for these weights. In Table 2, the results of the regression analysis are displayed, along with the estimated regression weights and p-values for all the predictors. Duration of transfusion was the only significant predictor of working memory in children with thalassemia $(\beta=-0.33, p=0.01)$. However, hemoglobin level $(\beta=-0.03, p=0.81)$ and ferritin level $(\beta=0.16, p=0.24)$ were not significantly affected working memory score. The variable hemoglobin level and duration of transfusion had a negative relationship with working memory since these variable were negatively affect working memory. The longer the children were diagnosed and treated with thalasemia, the lower the hemoglobin, which was related to lower working memory score. Collectively, all three predictors account for about $12 \%$ of the variance in working memory score $\left(\mathrm{R}^{2}=0.12\right)$. 
Table 1. Patient characteristics $(n=60)$.

\begin{tabular}{|c|c|c|}
\hline Characteristics & Mean (SD) & Number $(\%)$ \\
\hline General & - & - \\
\hline Age (years old) & $10.23(1.15)$ & - \\
\hline Gender & - & - \\
\hline Male & - & $29(48.33)$ \\
\hline Female & - & $31(51.67)$ \\
\hline Clinical & - & - \\
\hline Serum hemoglobin level (g/dL) & $6.04(0.65)$ & - \\
\hline Serum ferritin level $(\mu \mathrm{g} / \mathrm{L})$ & $4,297.90(2,116.42)$ & - \\
\hline Duration of transfusion (years) & $9.20(1.46)$ & - \\
\hline Working Memory & - & - \\
\hline Digit Span Forward & $4.68(1.05)$ & - \\
\hline Above average & - & $31(51.67)$ \\
\hline Below average & - & $29(48.33)$ \\
\hline Digit Span Backward & $2.78(0.94)$ & - \\
\hline Above average & - & $15(25.00)$ \\
\hline Below average & - & $45(75.00)$ \\
\hline Total Digit Span & $7.47(1.7)$ & - \\
\hline Above average & - & $17(28.33)$ \\
\hline Below average & - & $43(71.67)$ \\
\hline Academic Achievement & - & - \\
\hline Subjective & $47.73(11.28)$ & - \\
\hline School marks & $14.13(5.48)$ & - \\
\hline Total & $61.87(14.97)$ & - \\
\hline Quality of Life & - & - \\
\hline Physical & $71.36(20.40)$ & - \\
\hline Emotional & $82.08(20.24)$ & - \\
\hline Social & $81.92(22.11)$ & - \\
\hline School & $44.83(16.97)$ & - \\
\hline Total & $70.05(14.42)$ & - \\
\hline
\end{tabular}

Table 2. Association between severity and duration of illness on working memory.

\begin{tabular}{|c|c|c|}
\hline Characteristics & $\boldsymbol{\beta}$ & $\mathbf{p}$ \\
\hline Working memory score $\leftarrow$ Hemoglobin level & -0.03 & 0.81 \\
\hline Working memory score $\leftarrow$ Ferritin level & 0.16 & 0.24 \\
\hline Working memory score $\leftarrow$ Duration of transfusion & -0.33 & 0.01 \\
\hline
\end{tabular}

Squared Multiple Correlations $\left(\mathrm{R}^{2}\right)$ of Working memory score $=0.12$

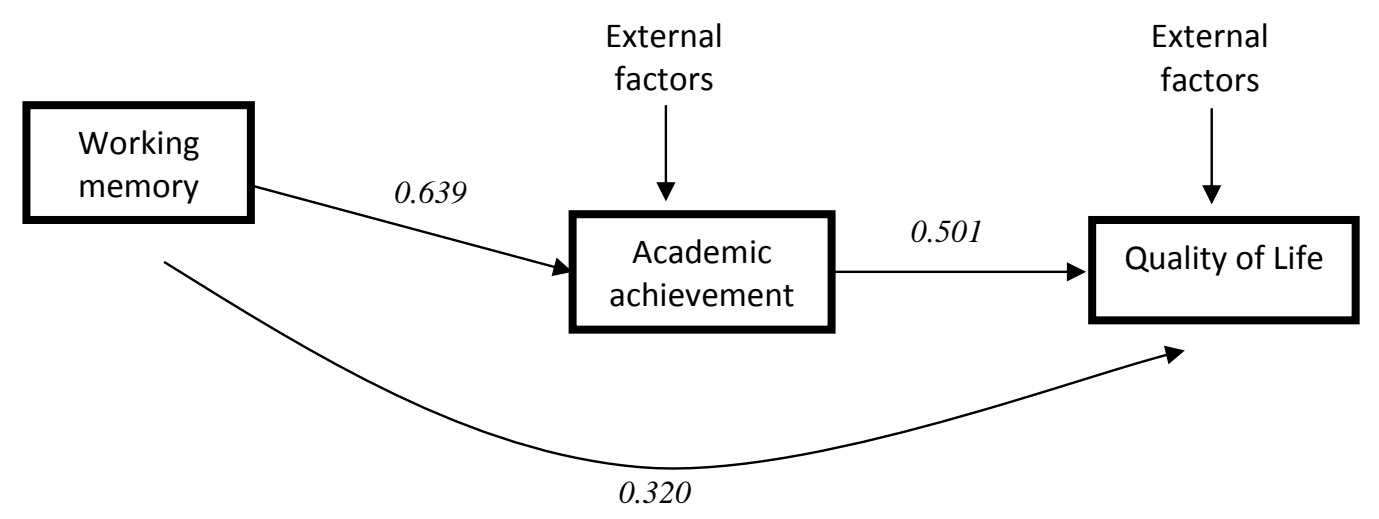

Fig. (2). Path analysis results. 
Path analysis was carried out and path coefficients were calculated by a series of multiple regression analyses based on the hypothesized model. The values in the final path were $\mathrm{P}>0.05$, RMSEA $<0.05, \mathrm{GFI}>0.9$, AGFI $>0.9, \mathrm{NFI}>0.9$, and CFI $>0.9$, which suggest that this path model fits the data quite well. The results of the direct and indirect components of the final path model are presented in Fig. (2). Quality of life in children with beta thalassemia was directly $(\beta=0.32)$ predicted in a positive direction by working memory and academic achievement. Additionally, working memory also affected quality of life indirectly $(\beta=0.639)$. The explanatory variables (working memory) accounted for $40.8 \%$ of the variance explaining academic achievement. The overall model variables accounted for $25.1 \%$ of the variance of quality of life in children with beta thalassemia.

\section{DISCUSSION}

Our study shows that almost three-quarter (71.67\%) children with beta thalassemia major suffer from working memory impairment which significantly $(p<0.001)$ influences their academic achievement and quality of life.

Several studies show that cognitive function is significantly lower in patients with beta thalassemia. In most cases, this complication remains subclinical and is only detected during neuropsychological evaluations [6]. Cognitive function impairment was first described by Orsini et al [33 - 34]. and Raafat et al. in a study on 100 beta thalassemia children and 100 healthy controls using Wechsler Intelligence Scale for Children-Third Edition (Arabic version). The study showed that the mean Full-Scale IQ and Performance IQ of patients were significantly lower than those of controls [35]. Duman et $a l$ in a study on 20 children with beta thalassemia major found that Full-Scale IQ, Verbal IQ, and Performance IQ scores are lower in patients [36]. Monastero et al. assessed cognitive function in 46 beta thalassemia major patients and 46 controls showed a significantly impaired cognitive function based on all neuropsychological batteries [37].

With regards to clinical and laboratory variables, this study fails to find a relationship between working memory and hemoglobin and ferritin levels. On the other hand, the duration of transfusional therapy was found to significantly affect working memory. A study from Monastero [37], Elshafy [38], and Elhabiby [39] also showed similar results. Thus, the chronic state of the disease itself, rather than the severity of anemia, is thought to be more involved in the development of cognitive deficits in thalassemic patients [37]. This notion is supported by a study using MR imaging from Manfre et al. which stated that the frequency of brain damage increases with age in patients with thalassemia [15].

Working memory is the ability to process and remember information. It is linked to a range of cognitive activities from reasoning tasks to verbal comprehension [40]. Alloway et al. in their study suggested that working memory at the start of formal education is a more powerful predictor of subsequent academic success than IQ [11]. Specific assessment of working memory in children with beta thalassemia has never been studied. Earlier study using Wechsler Intelligence Scale for Children-Third Edition from Zafeiriou et al. reported that
$36.36 \%$ of beta thalassemia patients had abnormal IQ [41]. The best explanation for the large number of patients suffering from working memory impairment in our study is that we involve relatively severe patients with severe anemia, longer duration of illness, high level of ferritin level requiring chelating agent therapy, and high possibility of thrombotic risk.

Nemtsas mentioned that chronic hypoxia and iron overload contribute to neurological manifestations of beta thalassemia [6]. Children with beta thalassemia live with chronic anemia condition which leads to chronic hypoxic state. A study by $\mathrm{Ai}$ et al stated that children with low hemoglobin levels have significantly lower scores in Performance IQ and the group of children with high iron but low hemoglobin levels have the worst score [42]. Sun explained that memory is extremely sensitive to hypoxia-ischemia due to the fragility of hippocampal neurons and network to hypoxia. Hippocampal neurons and network itself play an essential role in memory consolidation [43].

High level of ferritin serum or hemosiderosis leads to iron deposition in body. The evidence of iron brain deposition in beta thalassemia patients has never been studied using either neuroradiological or neuropathological examination. Schipper in his study using magnetic resonance scanning on patients with neurodegeneration with brain iron accumulation who also suffered from body iron homeostasis disturbance stated that there are predominantly pathological deposition of metal within the central nervous system. [44] Monastero et al. stated that hemosiderosis plays a potential role in cognitive functioning. It is also strengthened by their observation in the same study which showed that patients with signs of iron overload tend to perform worse on neuropsychological tests [37]. A study by Ma'ani et al. showed that serum ferritin level in children with beta thalassemia is associated with their cognitive functioning when assesed using Mini Mental State Examination tools [23] whereas Retnani stated that high serum ferritin level correlates with low cognitive function in thalassemia major children, specifically in performance IQ [45].

Beta thalassemia patients experience hypercoagulable state which leads to thrombotic risk. A study of the hypercoagulable state in beta thalassemia patients using thromboelastography examination showed that $5 \%$ of patients are considered to have hypercoagulable condition [20]. Schatz in a study on children with sickle cell disease which shares similar condition with beta thalassemia stated that majority of sickle cell patients perform poorly on the digit span-backward [46]. Their results are similar to this study. Magnetic resonace study on sickle cell children showed that frontal lobe is the most common location of injury, and that it relates to reduced efficiency in rehearsing verbal information in working memory, difficulties in manipulating verbal information in working memory, and poorer retrieval of verbal information on memory recall trials [47].

Working memory capacity is directly related to mathematical skills, language comprehension, and reading ability. Children with low working memory capacity also show short attention spans, are easily distracted, and tend to forget instructions. [11] Rogers et al. in a study involving adolescents 
with attentional problems stated that working memory is a risk factor for academic failure [48]. Academic problem in school gives rise to limitations that could lead to low self-esteem and problems with acceptance by peers. Children with poor academic performance are exposed to a number of factors that could impact their quality of life [49]. During childhood, academic achievement is important because academic accomplishment is generally thought to determine an individual's future academic career and job opportunities [50]. A study by Crede et al showed that student's academic achievement positively correlates to life satisfaction and quality of life among adolescence in Germany [51]. A similar result is also showed in a study conducted by Rezende, stating that poor school performance has a negative impact on the quality of life and health perception of children [49].

Quality of life is an important aspect for every individual. Empiric evidence shows that pediatric patients with chronic health conditions and low quality of life scores are at risk for having higher healthcare demands and costs in the future [52]. Multiple factors contribute to the quality of life in children with beta thalassemia. To improve the quality of life in children with beta thalassemia, suitable programs aimed at providing psychosocial support and links between the patient, school officials, family, and physician are important, especially for improving school functioning score [27]. Present studies emphasize the importance of psychosocial factor contribution in quality of life in children with beta thalassemia. Thalassemia is thought to be one of the most challenging hematological disorders with no permanent cure. Although advanced medical management has increased the life expectancy, the quality of life of beta thalassemia patients is still relatively low and the psychosocial factors now take the primary importance [28].

Canatan et al. in a study performed in Antalya showed that $60 \%$ children with beta thalassemia have academic problems. Thavorncaroensap mentioned that school functioning subscale score is the lowest score of all health related quality of life aspects in children with beta thalassemia [27]. Those studies show that academic performance is an important aspect in the quality of life of children with beta thalassemia.

Without early intervention, working memory difficulties will not spontaneously be corrected as a child develops [11]. However, there is evidence that working memory functioning can be altered and it has been suggested that there is plasticity in the neural networks involved in working memory [53]. Interventions that address working memory limitations may be both remedial and compensatory with a general goal of improving performance in a deficient area while increasing the efficiency of the individual's normal working memory processes [54]. Specific teaching strategies and teaching materials, as well as individual formulated program such as remedial education sessions should ideally begin early in children with poor working memory [55]. A study by Loosli et al. showed that computerized-adaptive working memory intervention considerably improves children's performance in working memory task.9 In 2015, Smith et al. generated a study involving a large sample using a specific working memory training program which shows that working memory training has a significant benefit in everyday functioning [56].
This study shows that cognitive functioning, specifically working memory, has a significant effect on both academic achievement and quality of life of children with beta thalassemia. The mechanism underlying working memory impairment in beta thalassemia children has never been studied but it is currently thought to be the results of chronic hypoxia [16, 17], iron overload [21 - 23], and hypercoagulable state [18 20]. Impairment of working memory is an important concern because it comprises the ability of individual to temporarily hold information and work with it. In other words, working memory is a core of cognitive function. It is consistently shown to be important for aspects of everyday functioning including maintaining attention in daily activities and academic achievement, in particular in mathematical and language performance [56]. Pyschosocial factors contribute to both academic achievement and quality of life in children with beta thalassemia. Factors such as socioeconomic status, parent educational level, and poor school attendance due to trans-fusion are relatively hard to modified. Working memory, on the other hand, can be modified through a series of training and improved working memory will give benefits for all aspects of life functioning [54].

Working memory screening of children with beta thalassemia is feasible and an early adaptive working memory training for children with working memory problem may improve not only their working memory but also their every day functioning and their quality of life.

Academic achievement as well as quality of life of a child are influenced by many factors such as socio-economic, nutritional, and parent's educational level factors. The limitation of this study is that we did not analyse these external factors that may affect both academic achievement and quality of life. Better designed studies with larger sample sizes are required to understand the impact of cognitive function on the quality of life in children with thalassemia.

\section{CONCLUSION}

Working memory influences academic achievement and quality of life in beta thalassemia children. Working memory is a contributing factor that determines the quality of life of children with beta thalassemia, both directly and indirectly, via academic achievement. Early attention and intervention programs are needed to help children with beta thalassemia to achieve a better quality of life.

\section{ETHICS APPROVAL AND CONSENT TO PARTICIPATE}

The protocol of the study was approved by the Institutional Ethics Committee.

\section{HUMAN AND ANIMAL RIGHTS}

No Animals were used in this research. All human research procedures followed were in accordance with the ethical standards of the committee responsible for human experimentation (institutional and national), and with the Helsinki Declaration of 1975, as revised in 2013. 


\section{CONSENT FOR PUBLICATION}

Written parental informed consent and the child's assent were obtained prior to participation in the study.

\section{CONFLICT OF INTEREST}

The authors declare no conflict of interest, financial or otherwise

\section{FUNDING}

This study is a part of Academic Leadership Grant project funded by Universitas Padjadjaran, Bandung, Indonesia and has received no specific grant from any funding agency in the public, commercial, or other not-for-profit sectors.

\section{ACKNOWLEDGEMENTS}

We would like to extend our gratitude to all the staff and management of Pediatric Thalassemia Unit of Dr. Hasan Sadikin General Hospital, Bandung, Indonesia for their encouragement and support throughout the study.

\section{REFERENCES}

[1] Marengo-Rowe AJ. The thalassemias and related disorders. Proc Bayl Univ Med Cent 2007; 20(1): 27-31.

[http://dx.doi.org/10.1080/08998280.2007.11928230] [PMID: 17256 039]

[2] Higgs DR, Engel JD, Stamatoyannopoulos G. Thalassaemia. Lancet 2012; 379(9813): 373-83. [http://dx.doi.org/10.1016/S0140-6736(11)60283-3] [PMID: 21908 035]

[3] Fucharoen S, Winichagoon P. Haemoglobinopathies in southeast Asia. Indian J Med Res 2011; 134: 498-506. [PMID: 22089614]

[4] Bulan S, Tamam M, Soemantri A. Faktor-Faktor Yang Berhubungan Dengan Kualitas Hidup Anak Thalasemia Beta Mayor Ilmu Kesehatan Anak. Semarang: Universitas Diponegoro 2009.

[5] Majid S, Abidi M. Quality of life and coping styles of care-givers of patients suffering from thalassemia major. Int J Med Pharm Sci 2013; 3: 41-6.

[6] Nemtsas P, Arnaoutoglou M, Perifanis V, Koutsouraki E, Orologas A. Neurological complications of beta-thalassemia. Ann Hematol 2015; 94(8): 1261-5

[http://dx.doi.org/10.1007/s00277-015-2378-z] [PMID: 25903043]

[7] Werheid K, Hoppe C, Thöne A, Müller U, Müngersdorf M, von Cramon DY. The adaptive digit ordering test: clinical application, reliability, and validity of a verbal working memory test. Arch Clin Neuropsychol 2002; 17(6): 547-65.

[http://dx.doi.org/10.1093/arclin/17.6.547] [PMID: 14591855]

[8] Baddeley A. Working memory and language: An overview. J Commun Disord 2003; 36(3): 189-208.

[http://dx.doi.org/10.1016/S0021-9924(03)00019-4] [PMID: 12742 667]

[9] Loosli SV, Buschkuehl M, Perrig WJ, Jaeggi SM. Working memory training improves reading processes in typically developing children. Child Neuropsychol 2011; 1-17.

[PMID: 21623483]

[10] Alloway TP. How does working memory work in the classroom? Educ Res Rev 2006; 1: 134-9.

[11] Alloway TP, Alloway RG. Investigating the predictive roles of working memory and IQ in academic attainment. J Exp Child Psychol 2010; 106(1): 20-9.

[http://dx.doi.org/10.1016/j.jecp.2009.11.003] [PMID: 20018296]

[12] Shrager Y, Levy DA, Hopkins RO, Squire LR. Working memory and the organization of brain systems. J Neurosci 2008; 28(18): 4818-22. [http://dx.doi.org/10.1523/JNEUROSCI.0710-08.2008] [PMID: 18448 658]

[13] Lara AH, Wallis JD. The role of prefrontal cortex in working memory: A mini review. Front Syst Neurosci 2015; 9: 173

[http://dx.doi.org/10.3389/fnsys.2015.00173] [PMID: 26733825]

[14] Curtis CE, D'Esposito M. The effects of prefrontal lesions on working memory performance and theory. Cogn Affect Behav Neurosci 2004; 4(4): 528-39

[http://dx.doi.org/10.3758/CABN.4.4.528] [PMID: 15849895]

[15] Manfrè L, Giarratano E, Maggio A, Banco A, Vaccaro G, Lagalla R. MR imaging of the brain: Findings in asymptomatic patients with thalassemia intermedia and sickle cell-thalassemia disease. AJR Am J Roentgenol 1999; 173(6): 1477-80.

[http://dx.doi.org/10.2214/ajr.173.6.10584785] [PMID: 10584785]

[16] Micheloyannis S, Papadaki F, Jannopoulos A. The effect of blood transfusion on alpha EEG activity in thalassemic patients. Eur Neurol 1991; 31(3): 131-5.

[http://dx.doi.org/10.1159/000116662] [PMID: 2044625]

[17] Steen RG, Miles MA, Helton KJ, et al. Cognitive impairment in children with hemoglobin SS sickle cell disease: Relationship to MR imaging findings and hematocrit. AJNR Am J Neuroradiol 2003; 24(3): 382-9.

[PMID: 12637286]

[18] Cappellini MD. Coagulation in the pathophysiology of hemolytic anemias. Hematology (Am Soc Hematol Educ Program) 2007; 74-8. [http://dx.doi.org/10.1182/asheducation-2007.1.74] [PMID: 18024612]

[19] Sirachainan N. Thalassemia and the hypercoagulable state. Thromb Res 2013; 132(6): 637-41.

[http://dx.doi.org/10.1016/j.thromres.2013.09.029] [PMID: 24125597]

[20] Hastuti TS. Hubungan Volume Darah Transfusi dengan Koagulabilitas pada Penderita Thalassemia yang Mendapat Transfusi Berkala dan Belum Menjalani Splenektomi Ilmu Penyakit Dalam. Bandung: Universitas Padjadjaran 2011; pp. 40-56.

[21] Abdalla MY, Fawzi M, Al-Maloul SR, El-Banna N, Tayyem RF, Ahmad IM. Increased oxidative stress and iron overload in Jordanian $\beta$-thalassemic children. Hemoglobin 2011; 35(1): 67-79. [http://dx.doi.org/10.3109/03630269.2010.544624] [PMID: 21250883]

[22] Ikram N, Hassan K, Younas M, Amanat S. Ferritin levels in patients of beta thalassaemia major. Int J Pathol 2004; 2: 71-4.

[23] Ma'ani F, Fadlyana E, Rahayuningsih SE. Hubungan kadar ferritin serum dengan fungsi kognitif berdasarkan pemeriksaan status minimental (MMSE) pada penyandang thalassemia anak. Sari Pediatri 2015; 17: 163-8.

[http://dx.doi.org/10.14238/sp17.3.2015.163-8]

[24] Meymandi SH, Seyednezhad-Golkhatmi SH. Mandana and meymandi $\mathrm{H}$. A comparison of intelligence quotient in children with and without $\beta$-thalassemia major. Galen Med J 2015; 4: 132-8.

[25] Eiser C, Jenney M. Measuring quality of life. Arch Dis Child 2007; 92(4): 348-50.

[http://dx.doi.org/10.1136/adc.2005.086405] [PMID: 17376942]

[26] Siddiqui SH, Ishtiaq R, Sajid F, Sajid R. Quality of life in patients with thalassemia major in a developing country. J Coll Physicians Surg Pak 2014; 24(7): 477-80.

[PMID: 25052969]

[27] Thavorncharoensap M, Torcharus K, Nuchprayoon I, Riewpaiboon A, Indaratna $\mathrm{K}$, Ubol BO. Factors affecting health-related quality of life in Thai children with thalassemia. BMC Blood Disord 2010; 10: 1-10. [PMID: 20180983]

[28] Khurana A, Katyal S, Marwaha RK. Psychosocial burden in thalassemia. Indian J Pediatr 2006; 73(10): 877-80.

[http://dx.doi.org/10.1007/BF02859278] [PMID: 17090897]

[29] Conway ARA, Kane MJ, Bunting MF, Hambrick DZ, Wilhelm O, Engle RW. Working memory span tasks: A methodological review and user's guide. Psychon Bull Rev 2005; 12(5): 769-86.

[http://dx.doi.org/10.3758/BF03196772] [PMID: 16523997]

[30] Ostrosky $\square$ Solís F, Lozano A. Digit span: Effect of education and culture. Int J Psychol 2006; 41: 333-41.

[http://dx.doi.org/10.1080/00207590500345724]

[31] de Paula JJ, Malloy-Diniz LF, Romano-Silva MA. Reliability of working memory assessment in neurocognitive disorders: A study of the digit span and corsi block-tapping tasks. Br J Psychiatry 2016; 38(3): 262-3.

[http://dx.doi.org/10.1590/1516-4446-2015-1879] [PMID: 27579598]

[32] Stage RK, Carter HC, Nora A. Path analysis an introduction and analysis of a decade of research. J Educ Res 2004; 98: 5-13.

[http://dx.doi.org/10.3200/JOER.98.1.5-13]

[33] Reinard JC. Modelling communication behaviour. Communication Research Statistics 2006

[34] Orsini A, Soulayrol R, Tramini F, Tasso-Perrimond AM. Nervous manifestations associated with thalassemia (critical study of the concept of thalassemic neurohemolytic syndrome). Pediatrie 1967; 22(7): 771-84.

[PMID: 5596854] 
[35] Raafat N, Safy UE, Khater N, et al. Assessment of cognitive function in children with beta-thalassemia major: A cross-sectional study. J Child Neurol 2014; 1-6. [PMID: 25296920]

[36] Duman O, Arayici S, Fettahoglu C, et al. Neurocognitive function in patients with $\beta$-thalassemia major. Pediatr Int 2011; 53(4): 519-23. [http://dx.doi.org/10.1111/j.1442-200X.2010.03279.x] [PMID: 20964 788]

[37] Monastero R, Monastero G, Ciaccio C, Padovani A, Camarda R. Cognitive deficits in beta-thalassemia major. Acta Neurol Scand 2000; 102(3): 162-8

[http://dx.doi.org/10.1034/j.1600-0404.2000.102003162.x] [PMID: 109 87375]

[38] Abd-Elshafy AHA-E, Elsharkawy AA-E, Abd-Elmaksod YH, ElBakry ST. Cognitive Impairment in School-aged Children With Beta Thalassemia Pediatric. Egypt: Benha University 2013.

[39] Elhabiby MM, ElSalakawy W, Khalil SA, Hassan DI, Hjislam SG. Cognitive dysfunction in $\beta$-thalassemia major and intermedia patients and its clinical correlates. Middle East Current Psychiatry 2016; 3 : 128-33.

[http://dx.doi.org/10.1097/01.XME.0000484344.49943.1c]

[40] Kane MJ, Engle RW. The role of prefrontal cortex in working-memory capacity, executive attention, and general fluid intelligence: An individual-differences perspective. Psychon Bull Rev 2002; 9(4): 637-71.

[http://dx.doi.org/10.3758/BF03196323] [PMID: 12613671]

[41] Zafeiriou DI, Economou M, Athanasiou-Metaxa M. Neurological complications in $\beta$-thalassemia. Brain Dev 2006; 28(8): 477-81.

[http://dx.doi.org/10.1016/j.braindev.2006.02.005] [PMID: 16574362]

[42] Ai Y, Zhao SR, Zhou G, Ma X, Liu J. Hemoglobin status associated with performance IQ but not verbal IQ in Chinese preschool children. Pediatr Int 2012; 54(5): 669-75.

[http://dx.doi.org/10.1111/j.1442-200X.2012.03648.x] [PMID: 22507 306]

[43] Sun M-K. Hypoxia, ischemic stroke, and memory deficits: Prospects for therapy. IUBMB Life 1999; 48(4): 373-8.

[http://dx.doi.org/10.1080/713803535] [PMID: 10632564]

[44] Schipper HM. Neurodegeneration with brain iron accumulation clinical syndromes and neuroimaging. Biochim Biophys Acta 2012; 1822(3): 350-60

[http://dx.doi.org/10.1016/j.bbadis.2011.06.016] [PMID: 21782937]

[45] Retnani HI, Ismail D. Korelasi antara kadar feritin serum dan fungsi kognitif pada anak dengan thalassemia mayor Ilmu kedokteran klinik. Yogyakarta: Universitas Gadjah Mada 2013.
[46] Schatz J, Roberts CW. Short-term memory in children with sickle cell disease: Executive versus modality-specific processing deficits. Arch Clin Neuropsychol 2005; 20(8): 1073-85.

[http://dx.doi.org/10.1016/j.acn.2005.06.008] [PMID: 16139469]

[47] Brandling-Bennett EM, White DA, Armstrong MM, Christ SE, DeBaun M. Patterns of verbal long-term and working memory performance reveal deficits in strategic processing in children with frontal infarcts related to sickle cell disease. Dev Neuropsychol 2003; 24(1): 423-34.

[http://dx.doi.org/10.1207/S15326942DN2401_01] [PMID: 12850752]

[48] Rogers M, Hwang H, Toplak M, Weiss M, Tannock R. Inattention, working memory, and academic achievement in adolescents referred for attention deficit/hyperactivity disorder (ADHD). Child Neuropsychol 2011; 17(5): 444-58.

[http://dx.doi.org/10.1080/ 09297049. 2010.544648] [PMID: 21390 917]

[49] Rezende BA, Lemos SMA, Medeiros AM. QUALIDADE DE VIDA E AUTOPERCEPÇÃO DE SAÚDE DE CRIANÇAS COM MAU DESEMPENHO ESCOLAR. Rev Paul Pediatr 2017; 35(4): 415-21.

[http://dx.doi.org/10.1590/1984-0462/;2017;35;4;00009] [PMID: 29 185623]

[50] Kadison R, DiGeronimo TF. College of the overwhelmed: The campus mental health crisis and what to do about it. San Fransisco, CA: Jossey-Bass 2004

[51] Crede J, Wirthwein L, McElvany N, Steinmayr R. Adolescents' academic achievement and life satisfaction: the role of parents' education. Front Psychol 2015; 6: 52. [http://dx.doi.org/10.3389/fpsyg.2015.00052] [PMID: 25691877]

[52] Varni JW, Burwinkle TM, Seid M. The PedsQL as a pediatric patientreported outcome: Reliability and validity of the PedsQL Measurement Model in 25,000 children. Expert Rev Pharmacoecon Outcomes Res 2005; 5(6): 705-19.

[http://dx.doi.org/10.1586/14737167.5.6.705] [PMID: 19807613]

[53] Cockroft K. The role of working memory in childhood education: Five questions and answers. S Afr J Child Educ 2015; 5: 1-18.

[54] Dehn MJ. Working memory and academic learning: Assessment and intervention. New Jersey: John Wiley \& Sons, Inc 2008.

[55] Karande S, Kulkarni M. Poor school performance. Indian J Pediatr 2005; 72(11): 961-7.

[http://dx.doi.org/10.1007/BF02731673] [PMID: 16391452]

[56] Spencer-Smith M, Klingberg T. Benefits of a working memory training program for inattention in daily life: A systematic review and meta-analysis. PLoS One 2015; 10(3): e0119522. [http://dx.doi.org/10.1371/journal.pone.0119522] [PMID: 25793607]

\section{(C) 2019 Gamayani et al.}

This is an open access article distributed under the terms of the Creative Commons Attribution 4.0 International Public License (CC-BY 4.0), a copy of which is available at: https://creativecommons.org/licenses/by/4.0/legalcode. This license permits unrestricted use, distribution, and reproduction in any medium, provided the original author and source are credited. 